\title{
EFEKTIVITAS PERLAKUAN BERNYANYI UNTUK MENGURANGI PERILAKU MELTDOWN/TEMPER TANTRUMPADA REMAJA AUTIS
}

Perdinan Nababan

\begin{abstract}
ABSTRAK
Penelitian ini dilakukan untulk mengkaji efektivitas perlakuan pengaruh bertujuan untuk mengurangi perilaku meltdown/temper tantrum, pada remaja autis dengan memberikan perlakuan bernyanyi melalui desain eksperimen subjek tunggal ABA.

Pada penelitian ini menggunakan teori copingdalam strategi emotion-focused coping, dimana perlakuan bernyanyi dijadikan media bagi penyandang autis untuk pengalihan emosi negatif menjadi positif sehingga perilaku meltdown/temper tantrum menjadi berkurang.

Subjek penelitian seorang remaja perempuan penyandang autis yang berusia 16 tahun memiliki perilaku meltdown/temper tantrumyang khas. Penelitian ini dilakukan selama 30 kali pertemuan dengan perincian untuk baselinesebanyak 10 kali, treatmentsebanyak 10 kali, mengulangbaselinesebanyak 10 kali. Subjek diberikan perlakuan bernyanyi selama 120 menit selama 10 kali pertemuan.

Hasil penelitian menunjukkan adanya penurunan perilaku meltdown/temper tantrum setelah diberikan perlakuan bernyanyi selama 10 kali pertemuan. pada fasebaseline1-10, sebesar 288 kemunculan perilaku, fasetreatment 1-10,kemunculan perilakusebesar 68 kemunculan perilaku, fase mengulang baseline 1-10,sebesar 105. Hal ini menunjukkan bahwa treatment yang berupa perlakuan bernyanyi dapat digunakan untuk mengurangi perilaku meltdown/temper tantrum.
\end{abstract}

Kata Kunci :Autis; Bernyanyi; Perilaku Meltdown/Temper Tantrum

\section{THE EFFECTIVENESS OF TREATMENT THROUGH SINGING TO DECREASE MELTDOWN/TEMPER TANTRUM BEHAVIOR IN TEENAGERS WITH AUTISM}

\begin{abstract}
ABSTRAK
This research aims to examine the effectiveness of treatment to decrease meltdown/temper tantrum in teenagers with autism by giving singing treatment through single subject experiment design ABA.

This research used coping theory in the strategy of emotion-focused coping, in which singing treatment is used as the medium for teenagers with
\end{abstract}


autism to change the negative emotion into positive so that meltdown/temper tantrum behavior decreased.

The research subject was a 16-year-old girl with autism who has a specific meltdown/temper tantrum behavior. This research was conducted in 30 meetings: 10 meetings for baselinese, 10 meetings for treatment, and10 meetings for repeating baseline. The subject was given singing treatment for 120 minutes in each meeting for those ten meetings.

The result shows the decrease of meltdown/temper tantrum behavior after the subject was given singing treatment in ten meetings. In baseline phase 1-10 there were 288 times appearance of the behavior, in treatment phase there were 68 times appearance, and in repeating baseline 1-10 phase there were 105 appearance. This shows that treatment in the form of singing can be used to decrease meltdown/temper tantrum behavior.

Kata Kunci :Autism, Singing, meltdown/temper tantrum behavior

\section{A. PENDAHULUAN}

Di Indonesia, penyandang autisme pada tahun 2002 tercatat 1:150 anak autis artinya dalam 150kelahiran, terdapat satu anak autis. Tahun 2006 jumlahnya meningkat menjadi 1:110 anak autis, tahun 2008 jumlah meningkat kembali menjadi 1:100 anak autis dantahun 2012 jumlah perbandingan anak autis mencapai 1: 88 (Harnowo, 2012). Hal inimenunjukkan bahwa jumlah penyandang autis di Indonesia semakin lama semakinmeningkat.

Penyebab autisme di Indonesia ini belum dapat dipastikan. Siegel (2003) mengatakan bahwa penyebab autisme disebabkan oleh faktor genetik, kelainan neurotransmitor, kelainan peptida di otak, komplikasi saat hamil danbersalin, kekebalan tubuh, faktor pencernaan, vaksinasi dan keracunanlogam berat.

Autisme merupakan gangguan perkembangan pervasive yang meliputi semua aspek perkembangan mental (Durand dan Barlow, 2006). Coleman (2005) mengatakan bahwa autisme merupakan gangguan neurobiologis. Gangguan neurobiologis tersebut dikarenakan ada kegagalan informasi ke otak yang menyebabkan informasiyang diterima tidak sesuai dengan keadaan yang sebenarnya karena ada pengurangan purkinje cells dan peningkatan terhadap posterior cerebellar vermis dan hemispheres (Delong, 2005). 
Gangguan neurobiologis ini mengakibatkan penyandang autis memiliki tiga gangguan yaitu gangguan interaksi sosial, gangguan komunikasi, pola perilaku, minat dan kegiatan repetitive yang terbatas (Siegel, 2003). Gangguangangguan yang dimiliki penyandang autis mengakibatkan penyandang autis memiliki perilaku-perilaku yang berbeda dengan orang normal. Salah satunya adalah berjalan mondar-mandir, mengekspresikan emosi dengan cara berperilaku menangis mengeluarkan air mata secara terus menerus dari durasi yang instan hingga seharian, menangis sambil menjerit, mengekspresikan kemarahan dengan cara memukul (memukul diri sendiri atau orang lain, memukul benda yang ada disekitar), melemparkan benda, mengigit jari. Lipsky (2011) mengatakan bahwa, perilaku-perilaku tindakan emosional ini disebut juga perilaku meltdown/temper tantrum.

Pada lembaga pengobatan akupuntur autis dan hiperaktif yang dikunjungi penulis diketahui bahwa, remaja penyandang autis memiliki perilaku meltdown/temper tantrum berupa berjalan mondar-mandir, mengekspresikan emosi dengan cara berperilaku menangis mengeluarkan air mata secara terus menerus dari durasi yang instan hingga seharian, menangis sambil menjerit, mengekspresikan kemarahan dengan cara memukul (memukul diri sendiri atau orang lain, memukul benda yang ada disekitar), melemparkan benda, mengigit jari.

Karakteristik perilaku meltdowns/temper tantrum inisangat penting diketahui orangtua yang memiliki anak dengan penyandang autis. Ketidaktahuan orangtua dalam mendeteksi ciri-ciri perilaku meltdown/temper tantrum akan membuat orangtua melakukan solusi-solusi yang diluar akal sehat manusia.

Dewasa ini dikabarkan ada orangtua dalam menghadapi perilaku meltdowns/temper tantrum yang dialami anaknya dengan cara mengunci anak tersebut di dalam kamar, memarahi, membentak, mencubit dan memukul. Kozelle (2010) memberitakan bahwa ada seorang ibu tega membunuh kedua anaknya yang mengalami autis karena ketidaksabaran dalam menghadapi perilaku meltdowns/temper tantrum (http://edition.cnn.com). 
Lipsky (2011) mengatakan bahwa perilaku meltdowns/temper tantrum dapat diterapi dengan berbagai jenis metode untuk mengurangi perilaku meltdown/temper tantrum. Salah satu metodenya adalah aktivitas musik. Aktivitas musik ini dapat berupa bernyanyi, bermain musik dan mendengarkan musik. Musik memiliki kekuatan untuk menterapiutik seseorang tanpa obat-obatan.

Keefektifan ini dapat dibuktikan pada beberapa penelitian terdahulu. Penelitian Boso, Emanuele, Minazzi, Abbamonte, dan Politi (2007) menunjukkan bahwa, terapi musik memiliki efek terapiutik dalam jangka panjang, dimana individu-individu yang diberikan aktivitas musik berupa bernyanyi, bermain musik dan mendengarkan musik memiliki efek terapiutik yang dapat dirasakan langsung dan bertahan lama. Penelitian Wigram dan Gold (2006) mengatakan bahwa, terapi musik juga memiliki efek musik dalam jangka pendek yang efektif, dimana individu yang terlibat dalam merasakan langsung efek terapi musik tersebut.

Selain efek dalam jangka panjang dan pendek. Penelitian Kim, Wigram, dan Gold (2009) juga membuktikan bahwa, salah satu aktivitas musik berupa bernyanyi dapat meningkatkan emosi positif pada penyandang autis. Djohan (2009) mengatakan bahwa, musik memiliki kekuatan yang dapat menimbulkan respon emosi, dimana emosi terjadi karena adanya asosiasi antara musik dan proses atribusinya. Respon emosi tersebut dapat juga disebut dengan emosi estetis. Emosi ini berkaitan dengan proses atribusi emosi sebagai penilaian individu terhadap pengalaman emosinya, baik yang menyenangkan maupun tidak menyenangkan, serta terkait dengan pengamatan terhadap musik tertentu.

Merujuk pada keseluruhan pemaparan di atas, dapat ditarik hipotesis penelitian perlakuan bernyanyi efektif mengurangi perilaku meltdown/temper tantrum padaremaja autis 


\section{B. METODE PENELITIAN}

\section{Identifikasi Variabel Penelitian}
a. Variabel tergantung
:Perilaku meltdown/Temper Tantrum
b. Variabel bebas
:Bernyanyi

\section{Definisi Operasional Variabel Penelitian}

a. Perilaku meltdown/Temper Tantrum

Perilaku meltdown/temper tantrum adalah perilaku atau respons emosi terhadap adaptasi stress yang diselesaikan secara insting karena gangguan kognitif, distorsi persepsi dan penyempitan pengalaman sensorik dengan durasi dari instan sampai sehari atau secara bertahap, periodik dalam satu hari atau seminggu.

Ciri-ciri perilaku meltdown dapat dilihat dari perilaku-perilaku emosional negatif penyandang autis yaitu perilaku marahberupa melempar benda, memukul benda, mondar-mandir, menangis tanpa menjerit, menangis dengan menjerit.

b. Bernyanyi

Bernyanyi yang dilakukan kepada penyandang autis berdasarkan empat situasi aktivitas yaitu: interactive singing, yaitu penggunaan bentuk aktivitas musik yang menggunakan tindakan bernyanyi untuk menjalin sosial interaksi dan komunikasi antara terapis dan penyandang autis, song choices, yaitu bentuk aktivitas musik yang dilakukan terapis dengan mengedepankan keinginan penyandang autis untuk memilih musik/lagu apa yang diinginkan penyandang autis.

\section{Subjek Penelitian}

Subjek penelitian ini dipilih berdasarkan purposive sampling berjumlah satu orang subjek. Subjek ini berjenis kelamin perempuan, remaja berusia 16 tahun dan suka berperilaku meltdown/temper tantrum. 


\section{Lokasi dan Waktu Penelitian}

Penelitian ini dilakukan di pengobatan akupuntur autis dan hiperaktif. Arogya Mitra Klaten. Tempat ini merupakan pengobatan akupuntur, sekolah dan asrama yang terletak di Dukuh Ngemplak, Kalikotes, Klaten Jawa Tengah.Waktu penelitian dilakukan setiap hari Senin dan Jumat, selama 30 pertemuan. Penelitian dimulai pada tanggal 14 Januari 2013 dan berakhir pada tanggal 3 Mei 2013.

\section{Pengumpulan Data}

Pengumpulan data yang dilakukan penulis adalah observasi dan wawancara

\section{Desain Penelitian}

Pada penelitian ini, penulis menggunakan desain subjek tunggal dengan desain reversal A-B-A.

\section{Reliabilitas Antar Rater}

Pada penelitian ini realiabilitas antar rater berdasarkan observasi perilaku meltdown/temper tantrum dengan video kamera selama 120 menit dengan dinilai. Selanjutnya hasil penilaian antar rater diukur dengan statistik deskriptif mean.

\section{Analisis Data}

Pada Penelitian ini, analisis data yang digunakan adalah analisis data visual grafik (visual analisis of graphic data)

\section{Proses Penelitian}

Pada persiapan penelitian, penulis melakukan asesmen, penyusunan prosedur pelaksanaan aktivitas musik bernyanyi pada remaja autis, pemilihan rater.

Pada pelaksanaan penelitian, penulis melakukan pemberian Informed consentkepada orangtua subjek, selanjutnya penulis melakukan observasifase baselineyang dilakukan 10 kali pertemuan. Penelitian ini dimulai pada tanggal 14 Januari 2013 dan berakhir pada tanggal 22 Febuari 2013.Fase treatment dilakukan 
10 kali pertemuan. penelitian ini dimulai pada tanggal 25 Febuari 2013 dan berakhir pada tanggal 29 Maret 2013.Fase mengulang baseline dilakukan 10 kali pertemuan. penelitian ini dimulai pada tanggal 01 April 2013 dan berakhir pada tanggal 03 Mei 2013.

\section{HASIL PENELITIAN}

Pengukuran dalam penelitian ini menggunakan observasi cek-list perilaku meltdown/temper tantrum yang diisi oleh para rater.Pengukuran ini dilakukan pada saat baseline (sebelum treatment), kemudian selama treatment $10 \mathrm{kali}$ pertemuan, dan mengulang baseline (setelah treatment). Adapun data visual grafik tersebut sebagai berikut:

\section{Perilaku Meltdown/Temper Tantrum}

\section{a. Perilaku Meltdown/Temper Tantrum Melemparkan Benda}

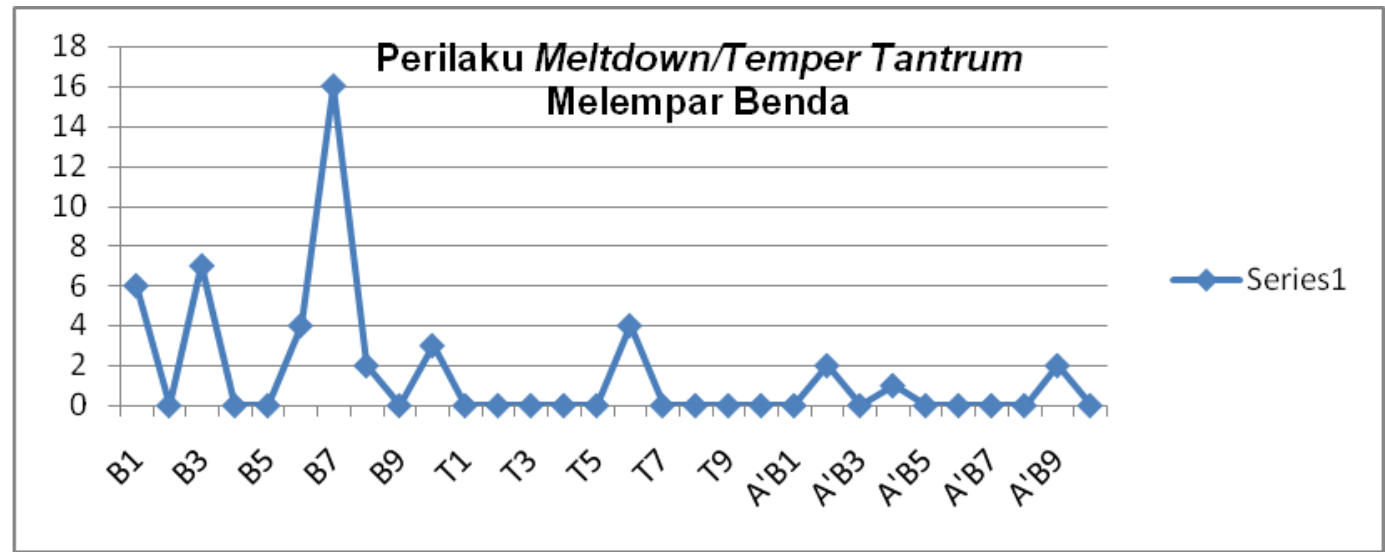

Tabel 1. Grafik Penurunan Perilaku Meltown/Temper Tantrum Melemparkan Benda

Dari grafik diatas pada (B1,B3,B6-B8,B10) menunjukkan perilaku meltdown/temper tantrum subjeksering muncul. Perilakumeltdown/temper tantrum yang paling sering muncul pada B7. Berdasarkan faktor penyebab perilaku meltdown/temper dikarenakanadanya faktor overload information. Faktoroverload informationterjadi saat guru subjek mengulangi terus materi pelajaran sehingga subjek tanpa jenuh.Timbal balik dari overload information ini mengakibatkan subjek pada baseline ke-7 tidak memperhatikan pelajaran yang diberikan guru, mencoret-coret buku, berjalan mondar mandir, berbicara sendiri. 
Pada (B2, B4, B5,B7,B9) subjek tidak menunjukkan perilaku meltdown/temper tantrummelempar benda.

Pada (T1-T5) dan (T7-10) tampak tidak menunjukkan kemunculan perilaku meltdown/temper tantrum melemparkan benda. Hal tersebut terjadi karena subjek dari awal mulai treatmenthingga berakhir treatment tampak fokus dan antusias mengikuti treatment bernyanyi. Subjek juga kadang sambil memegang tangan pelatih meminta tolong kepada untuk memutarkan lagu lagi. Subjek berkata "tambah lagi ya tolong... tolong T2 ya..tolong T2 ya".

Bentuk respons-respons dan lagu yang umumya ditunjukkan subjek berupa a) Respons subjek yang dimulai dengan menyebutkan judul terlebih dahulu, bertepuk tangan dan bernyanyi lagu T2 yang berjudul OK. b) Respons subjek bertepuk tangan terlebih dahulu, memberikan intro dengan bernyanyi "po..po..po selanjutnya bernyanyi lagu Layang-layang-Kevin dan Kak Nunu dan T2/OK. c) Respons subjek langsung bernyanyi dan bertepuk tangan umumnya pada lagu yang berjudul Agnes Monika/logika, Audy \& Nindy/Arti Sahabat, Nindji/Laskar Pelangi. d) Respons subjek langsung bernyanyi dan mengerakkan badannya biasanya pada lagu T2/OK dan Layang-layang/Kevin dan Kak Nunuk. e) Respons subjek hanya memperhatikan monitor sambil tersenyum-senyum biasanya lagu Weslife/Up town Girl. Lagu lagu ini adalah lagu yang paling sering diminta subjek dan pola respons subjek juga hampir sama di setiap treatment.

Treatment ke-6 subjek menunjukkan perilakumeltdown/temper tantrum melemparkan buku dan pulpen. Perilak meltdown/temper tantrum melemparkan benda diduga penulisdisebabkan overload emotional karena pada tanggal 15 maret 2014 ibu subjek kembali ke kota B setelah sebelumnya selama seminggu ibu subjek berada di asrama.

Fase mengulang baseline menunjukkan(A'B2,A'B4,A'B9) menunjukkan perilaku meltdown/temper tantrum subjeksering muncul. Perilaku perilaku meltdown/temper tantrum yang paling sering muncul pada (A'B2 dan A'B9) karena faktor overload information. Faktor overload information disebabkan guru subjek mengintruksikan untuk fokus sehingga menyebabkan subjek berperilaku 
meltdown/temper tantrum. Pada mengulang baseline ke (A'B1,A'B3,A'B5A'B7,A'B9) tidak menunjukkan perilaku meltdown/temper tantrum.

Secara keseluruhan fase baseline, treatment, mengulang baseline tampak ada penurunan. Hal ini terlihat pada fase baseline total nilai 38 kemunculan perilaku meltdown/temper tantrum dengan rentang skor maksimal 16 dan minimal 0 . Fase treatment total nilai 4 dengan rentang skor maksimal 4 dan minimal 0 , fase mengulang baseline total nilai 5 dengan rentang skor maksimal 2 dan minimal skor 0. Penurunan kemunculan yang semula 38 menjadi 5 berarti perubahan skor bernilai 33 .

b. Perilaku Meltdown/Temper Tantrum Memukul Benda

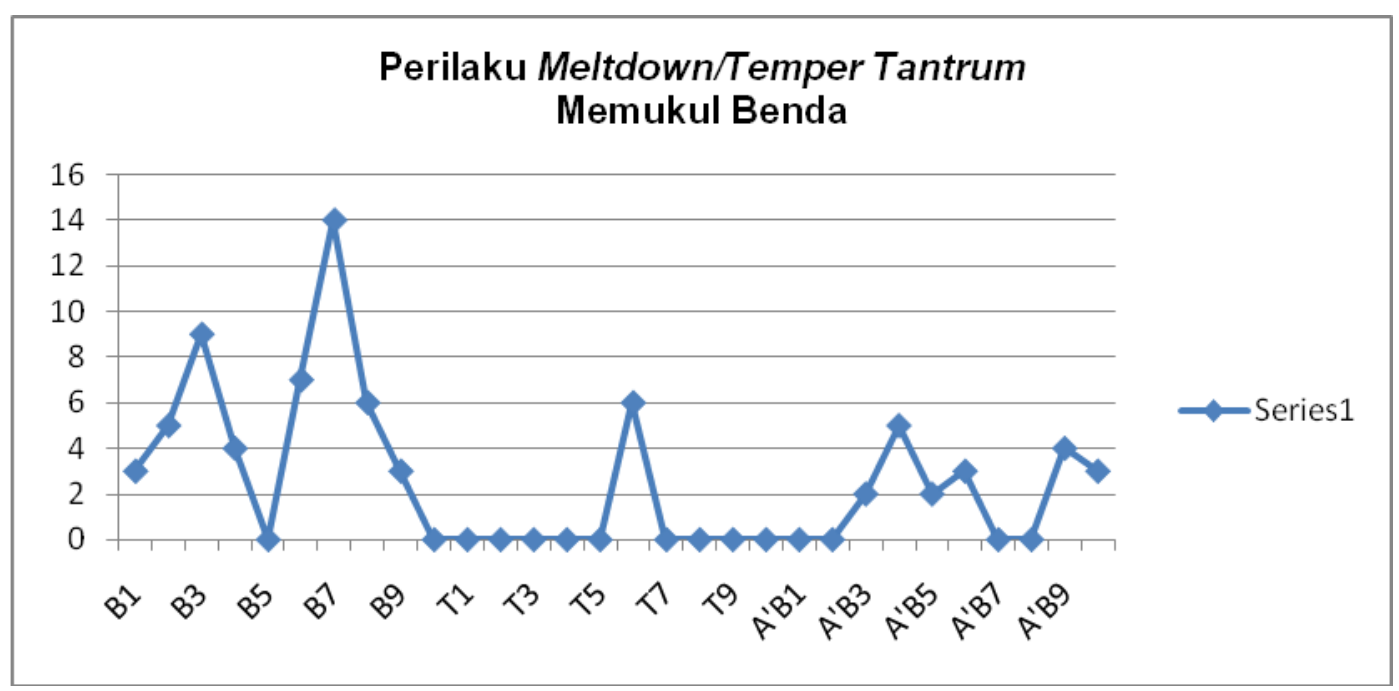

Tabel 2. Grafik Penurunan Perilaku Meltown/Temper Tantrum Memukul Benda

Dari grafik diatas pada (B1-B4) dan (B6-B9) menunjukkan perilaku meltdown/temper tantrum memukul benda sering muncul. Penulis menduga bahwa, perilaku meltdown/temper tantrum yang muncul dikarenakan faktor overload information. Hal tersebut terjadi karena subjek tidak fokus dalam 
menerima pelajaran sempoa (pelajaran pola berpikir logis dan matematika). Subjek cenderung menunjukkan beberapa perilaku memukul meja sampai berkalikali dan mencoret-coret buku lalu memukul meja dengan pulpen. .

Baseline ke-5 (B5) dan baseline ke-10 (B10) menunjukkan bahwa subjek tidak menunjukkan perilaku meltdown/temper tantrum. Hal ini dikarenakan subjek menunjukkan kondisi mood yang baik. Kondisi mood yang baik dapat dilihat dari subjek yang sering tersenyum.

Pada (T1-T5) dan (T7-10) tidak menunjukkan kemunculan perilaku meltdown/temper tantrum. Subjek tampak fokus dengan lagu yang disuka subjek. Subjek hanya melihat gambar yang ada dimonitor sambil tersenyum sendiri. Penulis menduga bahwa subjek berimajinasi dengan lagu yang dinyalakan. Jika pelatih ingin menganti lagu, subjek langsung berkata "jangan gangu..jangan ganggu".

Treament ke-6 (T6) subjek menunjukkan kemunculan perilaku meltdown/temper tantrum memukul benda yang ada di sekitar karena subjek dari awal masuk kelas sudah menampilkan perilaku meltdown/temper tantrum. tersebut.

Fase mengulang baseline menunjukkan(A'B2-A'B6) dan (A'B9-A'B10) perilaku meltdown/temper tantrum melempar benda. Umumnya subjek berperilaku melemparkan benda karena faktor overload information. Faktor overload information terjadi saat guru subjek mengulangi terus materi pelajaran sehingga subjek tanpa jenuh. (A'B1,A'B7,A'B8) tidak menunjukkan perilaku meltdown/temper tantrum.

Secara keseluruhan fase baseline, treatment, mengulang baseline tampak ada penurunan.Hal ini terlihat pada fase baseline total nilai 51 kemunculan perilaku meltdown/temper tantrum dengan rentang skor maksimal 14 dan minimal 0 , fase treatment total nilai 6 dengan rentang skor maksimal 6 dan minimal 0, fase mengulang baseline total nilai 19 dengan rentang skor maksimal 5 dan minimal skor 0. Penurunan skor yang semula 51 menjadi 19 berarti perubahan skor bernilai 32. 
c. Perilaku Meltdown/Temper Tantrum Mondar-mandir

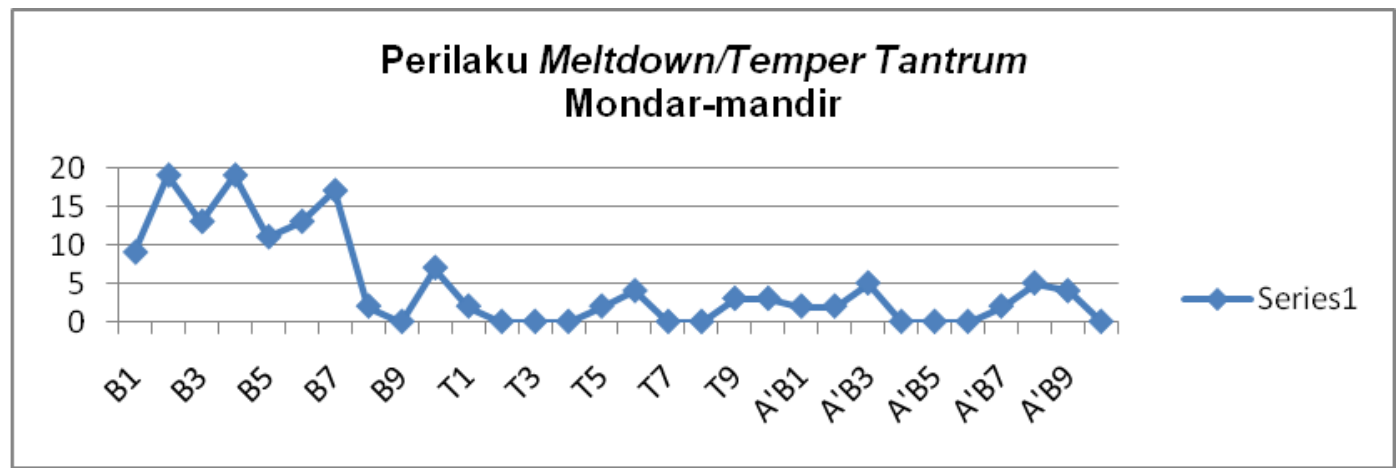

Tabel 3. Grafik Penurunan Perilaku Meltown/Temper Tantrum Mondar-mandir

Dari grafik diatas pada (B1-B8) dan (B10) menunjukkan perilaku meltdown/temper tantrum mondar-mandirsubjeksering muncul. Hal tersebut terjadi karena subjek tidak fokus dalam menerima pelajaran sempoa (pelajaran pola berpikir logis dan matematika).

Ketidakfokusan subjek ini menjadikan guru membentak subjek dan subjek kembali mengeluarkan perilaku meltdown/temper tantrum mondar-mandir dan berbicara tidak jelas maknanya misalnya, “jangan korupsi, nenek sihir, ya..ya”.

Pada (B9) subjek tidak menunjukkan perilaku meltdown/temper tantrum. Hal tersebut terjadi karena subjek memiliki kondisi mood yang baik, dibuktikan dari subjek yang dapat diajak komunikasi dan tersenyum. Subjek juga tampak fokus dalam mengikuti pelajaran yang diberikan guru.

Pada (T2-T4,T7,T8) tidak menunjukkan kemunculan perilaku meltdown/temper tantrum mondar-mandir. Hal tersebut terjadi karena subjek dari awal tampak fokus dan antusias, perilaku mondar-mandir subjek tidak muncul karena subjek lebih senang duduk, sambil membaca lirik lagu yang terdapat pada monitor. Ketika treatment bernyanyi dimulai subjek menyebutkan judul lagu terlebih dahulu dan bernyanyi dari awal lagu hingga akhir lagu. selanjutnya subjek meminta kepada pelatih untuk memutar lagu kesukaan subjek. Adapun lagu kesukaan subjek adalah OK/T2, Layang-layang/Kevin dan kak Nunuk, Mimpi Yang Sempurna/Peter Pan.

Treament ke (T1,T5,T6,T9,T10) subjek menunjukkan kemunculan perilaku meltdown/temper tantrum mondar-mandir yang ada di sekitar karena 
subjek dari awal masuk kelas sudah menampilkan perilaku meltdown/temper tantrumtersebut.

Pada (A'B1-A'B3) dan (A'B7-A'B9) tidak menunjukkan perilaku meltdown/temper tantrum mondar-mandir terlalu seringsedangkan pada (A'B4A'B6) dan (A'B10) menunjukkan perilaku meltdown/temper tantrum.

Secara keseluruhan, fase baseline, treatment, mengulang baseline tampak ada penurunan. Hal ini terlihat pada fase baseline total kemunculan perilaku berjumlah 137 dengan rentang skor maksimal 19 dan minimal 0. Fase treatment menunjukkan kemunculan perilaku berjumlahtotal nilai 14 dengan rentang kemunculan perilaku dari maksimal 4 dan minimal 0 . Fase mengulang baseline kemunculan perilaku bernilaitotal 20 dengan rentang skor maksimal 5 dan minimal skor 0 . Penurunan skor yang semula 110 menjadi 20 berarti perubahan skor bernilai 90 .

\section{d. Perilaku Meltdown/Temper Tantrum Berteriak}

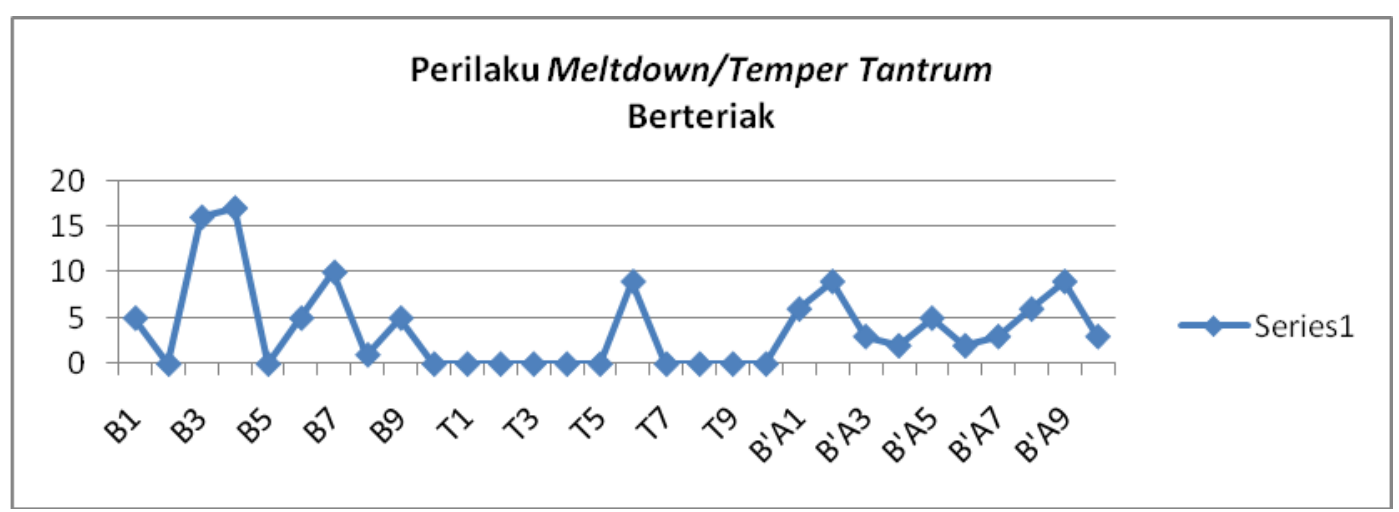

Tabel 4. Grafik Penurunan Perilaku Meltown/Temper Tantrum Berteriak

Dari grafik diatas pada (B1,B3,B4,B7,B8,B9) menunjukkan perilaku meltdown/temper tantrum berteriaksubjeksering muncul. Hal tersebut terjadi karena subjek tidak fokus dalam menerima pelajaran sempoa (pelajaran pola berpikir logis dan matematika).

Ketidakfokusan subjek dapat menjadikan subjek berteriak sangat keras sekali, kira-kira teriakan suara subjek terdengar sampai 20 meter. Teriakan ini akan semakin keras jika guru menginstruksikan subjek untuk menjawab pertanyaan guru. Penulis menduga bahwa, perilaku meltdown/temper tantrum berteriak dikarenakan faktor overload information. Overload information ini 
menajadikan subjek tidak menyukai instruksi yang berlebihan dan tugas sempoa yang diberikan guru.

Pada (B2,B10) subjek tidak menunjukkan perilaku meltdown/temper tantrum berteriak. Hal tersebut terjadi karena subjek memiliki kondisi mood yang baik, dibuktikan dari subjek yang dapat diajak komunikasi dan tersenyum. Subjek juga tampak fokus dalam mengikuti pelajaran yang diberikan guru.

Pada (T1-T5) dan (T7-10) tidak menunjukkan kemunculan perilaku meltdown/temper tantrum berteriakkarena subjek tampak senang untuk bernyanyi.

Bentuk respons-respons dan lagu yang umumya ditunjukkan subjek berupa a) Respons subjek yang dimulai dengan menyebutkan judul terlebih dahulu, bertepuk tangan dan bernyanyi lagu T2 yang berjudul OK. b) Respons subjek bertepuk tangan terlebih dahulu, memberikan intro dengan bernyanyi "po..po..po selanjutnya bernyanyi lagu Layang-layang-Kevin dan Kak Nunu dan T2/OK. c) Respons subjek langsung bernyanyi dan bertepuk tangan umumnya pada lagu yang berjudul Agnes Monika/logika, Audy \& Nindy/Arti Sahabat, Nindji/Laskar Pelangi. d) Respons subjek langsung bernyanyi dan mengerakkan badannya biasanya pada lagu T2/OK dan Layang-layang/Kevin dan Kak Nunuk. e) Respons subjek hanya memperhatikan monitor sambil tersenyum-senyum biasanya lagu Weslife/Up town Girl. Lagu lagu ini adalah lagu yang paling sering diminta subjek dan pola respons subjek juga hampir sama di setiap treatment.

Treament ke-6 (T6) subjek menunjukkan kemunculan perilaku meltdown/temper tantrum melempar benda yang ada di sekitar karena subjek dari awal masuk kelas sudah menampilkan perilaku meltdown/temper tantrum. tersebut.

Pada A'B1-A'B10 menunjukkan subjek berteriak sering namun tidak sesering fase baseline.

Berdasarkan keseluruhan fase baseline, treatment, mengulang baseline tampak ada penurunan. Hal ini terlihat pada fase baseline total nilai 59 kemunculan perilaku meltdown/temper tantrum dengan rentang skor maksimal 17 dan minimal 0, fase treatment total nilai 9 dengan rentang skor maksimal 9 dan minimal 0, fase mengulang baseline total nilai 48 dengan rentang skor maksimal 9 
dan minimal skor 0 . Penurunan skor yang semula 59 menjadi 48 berarti perubahan skor bernilai 11 .

\section{e. Perilaku Meltdown/Temper Tantrum Menangis Tanpa Menjerit}

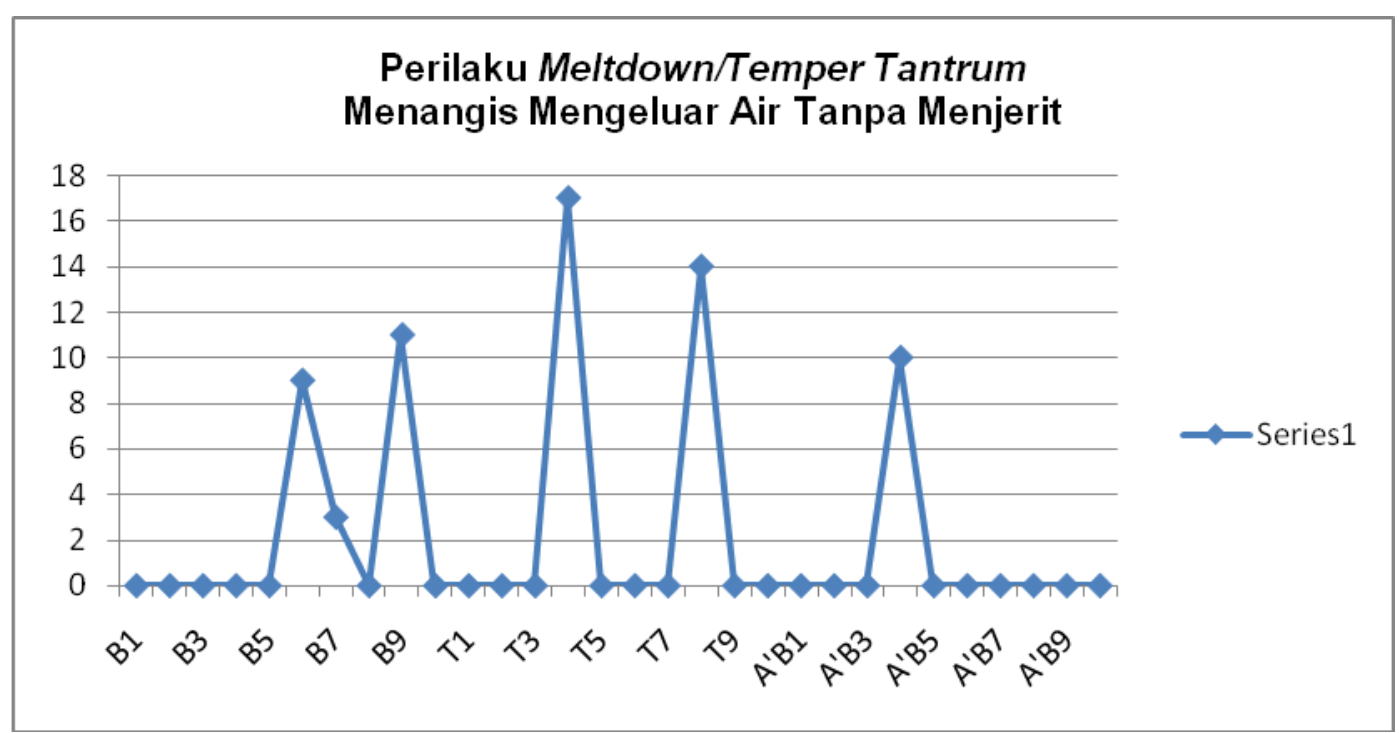

Tabel 5. Grafik Penurunan Perilaku Meltown/Temper Tantrum Menangis Tanpa Menjerit

Dari grafik di atas pada $(\mathrm{B} 6, \mathrm{~B} 7, \mathrm{~B} 9)$ menunjukkan perilaku meltdown/temper tantrum menangis tanpa menjeritsubjeksering muncul. Umumnya subjek menunjukkan perilaku menangis tanpa menjerit ditandai dengan subjek duduk terdiam, air mata mengalir tanpa sebab. Pada (B1-B5), B8, B10 subjek tidak menunjukkan perilaku meltdown/temper tantrum menangis tanpa menjerit.

Pada (T1-T5) dan (T7-10) tidak menunjukkan kemunculan perilaku meltdown/temper tantrum. Hal tersebut terjadi karena subjek dari awal tampak fokus dan antusias mengikuti treatment bernyanyi.

Treament ke-4 dan Treatment ke-8 subjek menunjukkan kemunculan perilaku meltdown/temper tantrum menangis dari awal masuk kelas. Subjek menangis sambil memeluk pelatih.

Pada (A'B1,A'B3,A'B5-A'B7,A'B9) tidak menunjukkan perilaku meltdown/temper tantrumberteriaksedangkan pada (A'B2,A'B4,A'B9) menunjukkan perilaku meltdown/temper tantrum. 
Secara keseluruhan perilaku meltdown/temper tantrum fase baseline, treatment, mengulang baseline tampak ada penurunan. Hal ini terlihat pada fase baseline total nilai 64 kemunculan perilaku meltdown/temper tantrum dengan rentang skor maksimal 11 dan minimal 0, fase treatment total nilai 31 dengan rentang skor maksimal 17 dan minimal 0, fase mengulang baseline total nilai 10 dengan rentang skor maksimal 10 dan minimal skor 0 . Penurunan skor yang semula 23 menjadi 10 berarti perubahan skor bernilai .13 .

\section{e. Perilaku Meltdown/Temper Tantrum Menangis dan Menjerit}

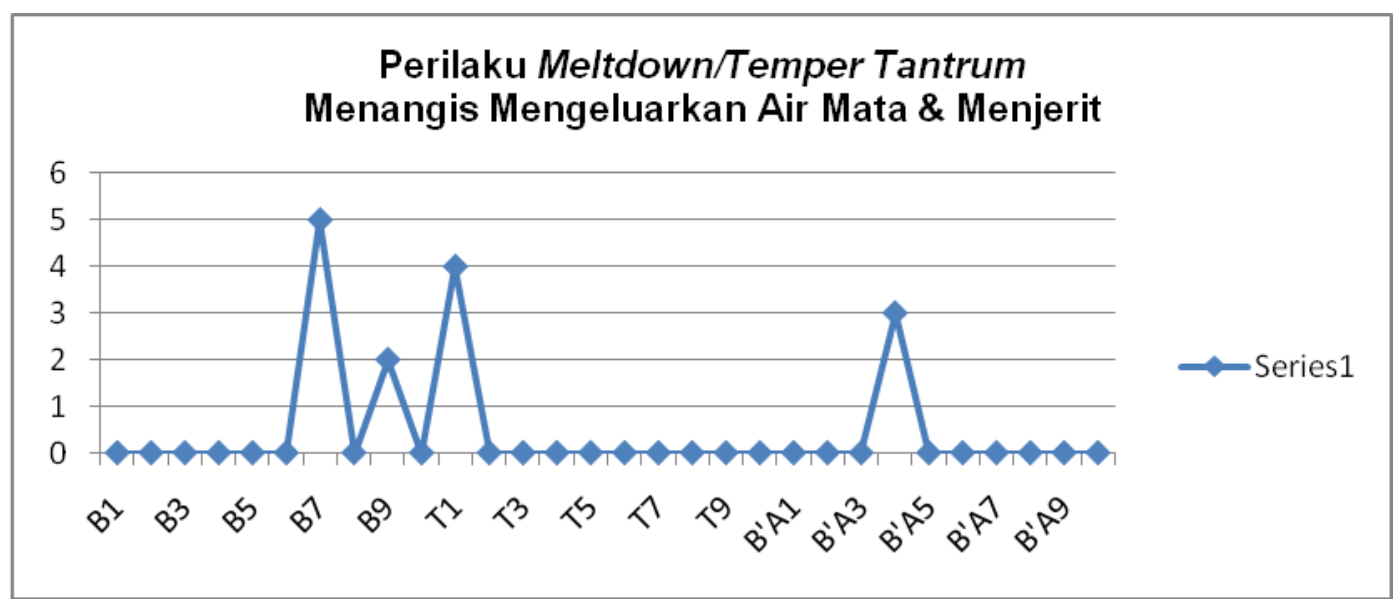

Tabel 6. Grafik Penurunan Perilaku Meltown/Temper Tantrum Menangis Sambil Menjerit

Dari grafik diatas pada $(\mathrm{B} 7, \mathrm{~B} 9)$ menunjukkan perilaku meltdown/temper tantrum menangis mengeluarkan air mata sambil menjeritsubjeksering muncul. Pada (B1-,B6) dan B8,B10) subjek tidak menunjukkan perilaku meltdown/temper tantrum menangis sambil menjerit.

Pada (T2-T10) tidak menunjukkan kemunculan perilaku meltdown/temper tantrum menangis sambil menjerit. Hal tersebut terjadi karena subjek dari awal tampak fokus dan antusias mengikuti treatment bernyanyi

Treament ke-1 (T1) subjek menunjukkan kemunculan perilaku meltdown/temper tantrum menangis sambil menjerit diduga hal ini terjadi karena faktor terlalu banyak permintaan. Treatment ke-1 terapis bertanya lagu apa yang diinginkan subjek, tanpa tampak bingung dan mendadak subjek menangis dan selanjutnya menjerit. 
Pada (A'B1,A'B3,A'B5-A'B7,A'B9) tidak menunjukkan perilaku meltdown/temper tantrum menangis tanpa menjeritsedangkan pada (A'B2,A'B4,A'B9) menunjukkan perilaku meltdown/temper tantrum.

Berdasarkan fase baseline, treatment, mengulang baseline tampak ada penurunan. Hal ini terlihat pada fase baseline total nilai 7 kemunculan perilaku meltdown/temper tantrum dengan rentang skor maksimal 5 dan minimal 2, fase treatment total nilai 4 dengan rentang skor maksimal 4 dan minimal 0, fase mengulang baseline total nilai 3 dengan rentang skor maksimal 3 dan minimal skor 0. Penurunan skor yang semula 7 menjadi 3 berarti perubahan skor bernilai 4 .

\section{PEMBAHASAN}

Perlakuan bernyanyi efektif mengurangi perilaku meltdown/temper tantrum pada remaja penyandang autis. Hal ini disebabkan perlakuan bernyanyi membuat remaja penyandang autis tersebut merasa senang dan mengerakkan tubuhnya untuk mengikuti beat lagu. Musik yang masuk ke telinga dalam bentuk elektromagnetik dan diteruskan ke otak yaitu mekanisme cerebellum. Pada saat yang bersamaan, zat kimia yang ada dalam otak yang disebut endorphin juga dilepaskan sehingga membuat anak menjadi senang dan mengerakkan tubuhnya untuk mengikuti beat lagu. Hasil penelitian ini mendukung hasil penelitian yang dikemukakan oleh Penelitian Boso, D’Angelo dan Barale (2013) menemukan bahwa musik dapat menjadi media yang sesuai untuk mengembangkan potensipotensi penyandang autis karena hanya musik yang mampu masuk ke dalam mekanisme cerebellum pada penyandang autis. Pengembangan ini dikarenakan salah satu elemen musik yaitu irama memiliki efek yang mampu mengaktifkan irama dalam otak penyandang autis secara alamiah yang berefek pada sensorik dan motorik penyandang autis.

Pada fasebaseline 1-10 dan mengulang baseline 1-10, subjek tampak tidak fokus sedangkan fase treatment bernyanyi subjek tampak antusias. Hal ini sejalan dengan pendapat Finnigan dan Starr (2010) bahwa, intervensi musik lebih efektif daripada intervensi non-musik. 
Ketidakfokusan subjek dalam mempelajari materi sempoa yang diberikan menjadikan guru memberikan instruksi lebih banyak. Intruksi yang banyak akan membuat subjek overload information. Subjek yang mengalami overload information selanjutnya akan mengalami perilaku meltdown/temper tantrum sehingga harus dialihkan agar perilaku meltdown/temper tantrum tidak terjadi secara berlebihan. Lipsky (2007) mengatakan bahwa cara menurunkan perilaku meltdown/temper tantrum yaitu dengan cara mengalihkan subjek, tidak mensugesti subjek, mencari media untuk mengalihkan perhatian subjek. Pengalihan perilaku meltdown/temper tantrum akan menjadikan emosi autis lebih stabil. Hal ini sejalan dengan temuan ini sejalan dengan penelitian penelitian Hillier, Greher, Poto \& Dougherty (2012) menemukan bahwa keterlibatan remaja autis dalam aktivitas musik dapat meregulasi emosi yang negatif menjadi positif. Selanjutnya penelitian Saarikallio (2007) mengatakan bahwa musik dapat menjadi media untuk meregulasi mood remaja autis. Penelitian Kim, Wigram, \& Gold (2009) mengatakan bahwa aktivitas musik dapat mengembangkan emosi positif pada penyandang autis.

Selain itu aktivitas musik ini juga sangat berguna bagi penyandang autis dalam tempo jangka panjang maupun pendek. Temuan ini menunjukkan aktivitas musik bernyanyi yang diberikan memiliki kekuatan dalam jangka panjang dan pendek. Penelitian Boso, Emanuele, Minazzi, Abbamonte, \& Politi (2007) mengatakan bahwa terapi musik memiliki efek terapiutik dalam jangka panjang sedangkan penelitian Wigram \& Gold (2006) mengatakan bahwa terapi musik dapat memberikan efek musik dalam jangka pendek.

\section{E. KESIMPULAN}

Berdasarkan hasil penelitian di atas, dapat disimpulkan bahwa perlakuan bernyanyi dapat mengurangi perilaku meltdown/temper tantrum pada remaja penyandang autis setelah diberikan perlakuan musik selama 10 kali pertemuan serta observasi dikelas sempoa selama 20 kali pertemuan, dengan memperhatikan keterbatasan dan kelemahan dalam penelitian ini. 
Pada fasebaseline 1-10, terlihat adanya kemunculan perilaku meltdown/temper tantrum sebesar 288 kemunculan perilaku meltdown/temper tantrum. Kemunculan perilaku meltdown/temper tantrum disebabkan subjek tidak fokus dalam mempelajari materi sempoa yang diberikan guru dan mengalami overload information dari guru.

Treatment 1-10 terlihat penurunan perilaku meltdown/temper tantrum dibandingkan baseline ke1-10. Penurunan ini dilihat dari kemunculan perilakuan fase baseline ke-1-10 sebesar 288 dibandingkan kemunculan perilaku fase treatment sebesar 68. Penurunan membuktikan bahwa, perlakuan bernyanyi efektif memfasilitasi penurunan perilaku meltdown/temper tantrum. Hal ini terjadi karena subjek sangat menyukai perlakuan bernyanyi dan fokus dalam bernyanyi. Subjek juga dapat membangkitkan ingatan subjek mengenai lirik lagu dan menari. Pada mengulang baseline 1-10, terlihat adanya kemunculan perilaku meltdown/temper tantrum namun tidak sesering baseline 1-10.

Berdasarkan hasil yang diperoleh dalam penelitian ini, maka diajukan saran sebagai berikut:

1. Bagi orangtua dan pengasuh penyandang autis diharapkan sering memberikan perlakuan bernyanyi untuk mengisi waktu luang penyandang autis.

2. Bagi penelitian selanjutnya, diharapkan dapat melakukan replikasi penelitian, dengan memperhatikan pemilihan lagu harus disesuaikan dengan penyandang autis, kemampuan pelatih, peneliti tidak boleh merangkap sebagai observer, terapis karena akan menimbulkan penilaian bias dan penggunaan CCTV.

\section{DAFTAR PUSTAKA}

Boso, M., D’Angelo, E., \& Barale, F. (2013). Neurophysiological correlates of musical giftedness in autism spectrum disorders. Music and Medicine, 5(4), 223-227.

Coleman, M. (2005). Neurological framework. Coleman, M. (Eds.), The neurology of autism (pp. 40-74). New York: Oxford University Press, Inc. 
Delong, R. (2005). The cerebellum in autism. Coleman, M. (Eds.), The neurology of autism (pp. 75-90). New York: Oxford University Press, Inc.

Djohan (2009). Respons emosi musikal. Yogyakarta:Lubuk Agung.

Durand, V. M \& Barlow, D. H. (2006). Essentials of abnormal psychology. USA: Thomson Wadsworth..

Harnowo, P. A. (2012, April 02). Hari autis sedunia: Jumlah anak autis di 2012 makin banyak. Health Detik. Retrieved from http://health.detik.com

Hillier, A., Greher, G., Poto, N., \& Dougherty, M. (2012). Positive outcomes following participation in a music intervention for adolescents and young adults on the autism spectrum. Psychology of Music, 40,(2), 201-215.

Kim, J., Wigram, T., \& Gold, C. (2009). Emotional, motivational and interpersonal responsiveness of children with autism in improvisational music therapy. Autism, 13(4), 389-409.

Kozelle, C. R. (2010, Juli 22). Woman in 911 call says she strangled her autistic children. CNN. Retrieved from http://edition.cnn.com.

Lipsky, D. (2011). From anxiety to meltdown: How individuals on the autism spectrum deal with anxiety, experience meltdowns, manifest tantrums, and how you can intervene effectively. London: Jessica Kingsley Publishers.

Saarikallio, S. (2007). The role of music in adolescents'mood regulation. Psychology of Music, 35(1), 88-109.

Siegel, B. (2003). Helping children with autism learn: Treatment approaches for parents and professionals. New York: Oxford University Press.

Sternberg, R. J. (2008). Psikologi kognitif (4 th Ed). Yogyakarta: Pustaka Pelajar 